\title{
MANAJEMEN SUMBER DAYA MANUSIA STRATEGIK: KESESUAIAN ANTARA STRATEGI SUMBER DAYA MANUSIA DENGAN STRATEGI BISNIS
}

\author{
Agus Fauzi \\ Magister Manajemen, Fakultas Ekonomi, Universitas Satya Negara Indonesia \\ Jalan Arteri Pondok Indah No.11 Jakarta Selatan
}

\begin{abstract}
This article aims to examine the new role of human resources, responsible for building organizational capability utilizing external opportunities. The new role of human resources as a strategic partner, administrative expert, employee champion, and change agents in each organization is different, including the heterogeneity or homogeneity of implementation and relations between various roles in question. Methods and approaches in this study using the study of literature. Literature in this study took on a variety of empirical research journals and books that discuss the new role of human resource management. Human resource professionals, often referred to as a business partner, which is narrowly defined as human resource professionals who work with general managers to implement the strategy as a strategic partner. This time understanding the business partners has changed a lot, not only as a strategic partner, but also as an administrative expert, employee champion and change agent. Results of the study also found that there are four levels of conformity (alignment) between the functions of human resources with strategic planning (business) namely administrative linkage, linkage one-way, two-way linkage, and integrative Linkage.
\end{abstract}

Keywords: Human Resources Management, Strategic Business

\section{PENDAHULUAN}

Sekarang ini, dunia bisnis tengah masuk pada era perubahan dan transformasi yang sedemikian cepat yang diakibatkan oleh penetrasi ilmu pengetahuan dan kontribusi perkembangan teknologi informasi, yang pada gilirannya muncul persaingan yang meningkat dan keinginan akan kebebasan untuk berbisnis dalam dan antar negara. Organisasi termasuk organisasi bisnis senantiasa dituntut agar menemukan teknik, mencari program dan visi, sehingga manajer dapat memperoleh kemampuan untuk menyesuai keahliannya pada tingkat perubahan radikal.

Adalah suatu keniscayaan, jika perubahan organisasi itu harus diikuti oleh perubahan sumber daya manusia secara memadai manakala lingkungan bisnis eksternal mengalami perubahan cepat dan dramatis. Saat ini juga terdapat konsensus yang mendunia, jika kebebasan pasar harus mendorong kondisi kehidupan ekonomi yang lebih baik dan menjanjikan dibanding sistem yang lain. Pasar bebas dan demokratisasi, privatisasi, pasar modal, joint ventures, entrepreneurship dan teknologi manufaktur menjanjikan kabar gembira akan kemakmuran dan kesejahteraan dunia. 
Tawaran pendekatan baru ini harus menjadi jalan masuk menuju perubahan, kemungkinan besar untuk adaptasi, menciptakan organisasi berorientasi global, meningkatknya kualitas dan standar kehidupan bagi umat manusia, tata kelola organisasi dengan banyak keberagaman etnik dan budaya. Organisasi-organisasi bisnis saat ini tengah memasuki abad 21 yang menjanjikan peluang sangat besar untuk perbaikan hidup. Dengan demikian, organisasi bisnis sudah sepantasnya menyadari atas dunia semakin berbagi dalam kekuatan bisnis dan kepemimpinan. Manajer organisasi dari berbagai negara saat ini berada pada posisi yang sedemikian penting dan strategik untuk perubahan.

Organisasi di setiap negara dan belahan bumi sudah selayaknya terus mencari upaya menjadi lebih baik dan akuntabel serta menyadari akan ketergantungannya pada kepiawaian sumber daya manusia guna mencapai pertumbuhan dan produktivitas bisnis. Produktivitas yang lebih tinggi tersebut pada gilirannya amat memungkinkan bagi organisasi membuat lebih banyak pilihan dan kemungkinan mencapai kepuasan pelanggan. Tak satupun terdapat misteri maupun keragu-raguan bahwa faktor utama meningkatkan produktivitas adalah pengelolaan sumber daya manusia secara tepat dan efektif. Setiap manajer organisasi harus merencanakan secara efisien, mengorganisir dengan sistematis dan mengarahkan sumber daya manusia secara efektif, melalui teknik, metoda dan pola kepemimpinan baru dan brilian melalui penyesuaian perubahan karyawan, visi bisnis dan strategi organisasional. Para manajer di abad 21 ini dituntut mempunyai pandangan tajam, pemikiran kritis, dan hasrat untuk menjadi lebih efektif untuk menciptakan produk unik dan kualitas tinggi, serta mampu menyerahkan pelayanan sebaik mungkin bagi pelanggan. Keniscayaan manajer organisasi untuk mengelola sumber daya manusia secara optimal sudah bukan lagi menjadi pertanyaan, melainkan menjadi sesuatu yang harus dijawab dan pantas direalisasikan dalam praktek bisnis melalui perbaikan secara terus menerus, agar meningkatnya kinerja organisasi menjadi lebih maksimal. Organisasi adalah suatu unit yang setidaknya terdiri dari dua orang yang seharusnya terus terkoordinasi dengan baik untuk menggapai serangkaian tujuan tertentu.

Organisasi merupakan wahana yang memungkinkan seseorang mencairkan kinerjanya dan meraih hasil yang sebelumnya tidak dapat dicapai individu secara sendiri-sendiri. Para karyawan sudah sewajarnya menuntut pembayaran yang adil, transparan dan proporsional atas kinerja yang dikontribusikannya. Di sisi lain, manajer mengharapkan organisasi mampu memenangkan persaingan bisnis dan memotivasi karyawan agar berkinerja jauh lebih baik. Sementara para pemilik ingin mendapatkan laba yang terus meningkat. Perilaku-perilaku yang demikian berbeda itu pasti ada pada setiap organisasi. Di antara beragam ilmu, ilmu manajemen sumber daya manusia merupakan ilmu yang selalu saja menarik untuk dipelajari, karena mengelola sejumlah individu untuk pencapaian tujuan-tujuan organisasi yang telah ditetapkan sebelumnya sangat penting. Pengelolaan sumber daya manusia tidak bisa mengesampingkan teknologi terkini yang nantinya diharapkan akan melahirkan inovasi. Inovasi menjadi faktor utama kerberhasilan organisasi di masa sekarang dan akan datang, yang merupakan bagian dari kehandalan sumber daya manusia. Perubahan lingkungan yang turbulensi melanda dunia bisnis dengan dihadapkan berbagai kecenderungan perubahan radikal, tuntutan akselerasi dan perubahan teknologi, globalisasi dan persaingan tinggi antar organisasi, perubahan struktur demografi, serta perubahan yang menfokuskan pada kecepatan informasi. Situasi seperti ini mengakibatkan perubahan dalam pengelolaan organisasi guna mengantisipasi persaingan bisnis, melalui pengelolaan sumber daya manusia dalam organisasi yang senantiasa diperbaharui menjadi lebih baik, profesional, dan berkelanjutan. Kecenderungan dan perubahan global tadi memiliki implikasi dan pengaruh baik secara langsung maupun tidak langsung terhadap perkembangan bisnis organisasi yang 
nantinya perlu mendapat penanganan secara profesional terutama dalam hal sumber daya manusia, tentunya disamping dari sisi permodalan.

Salah satu perubahan yang signifikan yaitu perkembangan teknologi manufaktur yang berdampak pada penggunaan sumber daya manusia yang lebih terampil dan memerlukan sumber daya yang lebih sedikit untuk menghasilkan kuantitas produk yang sama. Walaupun perubahan global diyakini bisa meningkatkan tingkat kesejahteraan secara umum, namun juga bisa menimbulkan permasalahan baru bagi organisasi. Organisasi sudah sepantasnya mengadaptasi dengan perubahan yang ada, baik di dalam maupun diluar organisasi. Pengambilan keputusan di semua tingkatan manajemen dalam organisasi sudah harus dipandang sebagai perubahan yang diperlukan agar lebih disesuaikan dengan tuntutan dan perubahan tersebut, terutama perubahan eksternal, misalnya perubahan selera konsumen.Fungsi manajemen sumber daya manusia seperti penyediaan staf, pengembangan sumber daya manusia, pelatihan, kompensasi, keselamatan dan kesehatan, serta hubungan antara karyawan merupakan salah satu tolak ukur yang sangat penting bagi sebuah perusahaan dalam rangka mencapai tujuan yang telah ditetapkan.

Tetapi manajemen sumber daya manusia tidak cukup hanya membahas tentang bagaimana penyediaan karyawan saja, namun juga membahas tentang bagaimana membentuk karyawan-karyawan itu menjadi sumber daya manusia yang berkualitas tinggi yang bisa berkontribusi besar bagi organisasi. Era globalisasi memunculkan banyak organisasi multi nasional yang sudah lintas negara bahkan benua. Produk yang dihasilkan perusahaan bukan hanya ditujukan untuk memenuhi permintaan di negara tempat perusahaan berada, namun juga untuk memenuhi pasar di negara lain. Dalam melakukan melakukan ekspansi perusahaan secara luas maka menimbulkan tuntutan kepada karyawan/pimpinan perusahaan untuk dapat berpikir global dan bertindak lokal. Bahkan banyak perusahaan multinasional yang memindahkan basis produksinya ke wilayah yang lebih dekat dengan pasar untuk mengurangi biaya pengiriman, dan ada juga yang memindahkan lokasi pabrik ke negara dengan tingkat upah karyawan yang lebih rendah dibanding negara asal.Perubahan teknologi yang terus berkembang akan bisa menggeser pekerjaan dari satu tempat ke tempat lain. Mesin sebagai salah satu bentuk kemajuan teknologi akan bisa menggantikan pekerja bagian manufaktur sehingga kebutuhan pekerja bisa menurun, sementara pekerjaan-pekerjaan teknik, manajerial, dan profesional akan meningkat. Partisipasi manajemen sumber daya manusia sangat penting dalam merancang ulang struktur pekerjaan, rencana-rencana insentif dan kompensasi, uraian jabatan baru ditulis, seleksi karyawan baru, evaluasi pekerjaan, dan program pelatihan yang disesuaiakan dengan kebutuhan organisasi. Perkembangan teknologi juga akan mendorong dalam peningkatan persaingan diantara organisasi menjadi lebih kompetitif. Perubahan teknologi berperan penting dalam mendorong perubahan struktur bisnis serta mendorong terciptanya bisnis baru yang memanfaatkan kemajuan teknologi. Banyak organisasi mengalami penurunan penjualan karena tidak tepat dalam mengantisipasi perubahan teknologi seperti Kodak dan Nokia, namun banyak juga organisasi baru yang sangat maju dalam waktu relatif cepat dengan modal yang kecil karena penggunaan teknologi yang diterima pasar, misalnya Google dan Facebook.

Perubahan demografi seperti komposisi angkatan kerja yang terus berubah disertai adanya lonjakan jumlah wanita dan semakin tuanya angkatan kerja membuat angkatan kerja menjadi semakin beragam. Jumlah yang besar dari wanita dalam angkatan kerja mengharuskan implementasi dari pilihan penjadwalan kerja yang lebih lentur dan menuntut perhatian yang lebih besar terhadap peluang promosi pekerjaan bagi kaum wanita. Pada angkatan kerja yang semakin tua akan berakibat pada peningkatan biaya pemeliharaan 
kesehatan dan sumbangan pensiun yang harus dibayarkan. Keragaman yang meningkat ini menjadi tugas sekaligus tantangan dalam fungsi manajemen sumber daya manusia. Demikian juga dengan adanya trend ke arah penggunaan yang meningkat atas pekerja paruh waktu dan pekerja kontrak dalam organisasi. Hal ini menimbulkan banyak tuntutan pekerja terutama di negara berkembang akibat ketidakpastian dimasa datang, bahkan ironisnya gaji yang diterima pekerja kontrak justru lebih sedikit dibanding gaji yang diterima pekerja tetap. Peran manajemen sumber daya manusia sangat diperlukan dalam menangani permasalahan ini untuk keberhasilan organisasi. Kecenderungan peningkatan jumlah pekerjaan di sektor jasa, pekerjaan yang berdasar pengetahuan dan modal manusia, menjadikan pergeseran besar dari pekerjaan manufakturing ke pekerjaan jasa. Sehingga banyak angkatan kerja yang dipekerjakan untuk menghasilkan dan menyerahkan jasa, dan bukan produk. Bahkan banyak negara yang makmur karena memiliki pekerjaan jasa seperti Singapura. Adanya pertumbuhan yang pesat pada industri jasa seperti katering, retail, konsultan, pekerjaan di bidang hukum, pekerjaan mengajar, dan lain sebagainya.

Pekerjaan-pekerjaan ini, pada gilirannya akan menuntut tipe baru dari pekerjaan yang berdasar pada pengetahuan dan metode manajemen sumber daya manusia yang baru untuk mengelola mereka dengan lebih baik. Bisnis yang akan sukses dalam jangka panjang memerlukan formulasi strategis yang tidak mudah, tapi harus direncanakan secara seksama dan antisipatif terhadap lingkungan internal dan eksternal, dengan elemen kunci keberhasilan organisasi adalah di manajemen sumber daya manusia.

Setiap ada perubahan maka akan mempengaruhi dan berdampak pada perubahan strategi bisnis untuk selalu berada di jalur yang benar menuju pada tujuan organisasi. Fluktuasi perekonomian menuntut organisasi untuk selalu mengikuti perkembangan dan mampu menyesuaikan diri dengan lingkungan ekonomi suatu negara. Ketika perekonomian dalam saat keemasan, maka organisasi bisa melakukan strategi ekspansif, misalnya dengan membanguna pabrik baru dan meningkatkan produksinya. Sementara pada saat perekonomian mengalami kontraksi, maka organisasi perlu melakukan efisiensi dalam menjalankan roda bisnisnya. Keunggulan kompetitif perusahaan dapat dicapai dan dipertahankan dengan cara perusahan lebih fleksibel dalam merespon perubahan dan perkembangan lingkungan bisnis, melalui transformasi organisasi maupun fungsi sumber daya manusia. Transformasi organisasi dilaksanakan agar organisasi menjadi fleksibel, kreatif, dan efisien, sedangkan transformasi fungsi sumber daya manusia dimaksudkan untuk menghasilkan sumber daya manusia yang memiliki kapabilitas untuk berpartisipasi dalam proses perubahan organisasi dalam mencapai tujuannya. Manajemen sumber daya manusia merupakan bidang strategis dari organisasi karena, manajemen sumber daya manusia harus dipandang sebagai perluasan dari pandangan tradisional untuk mengelola orang secara efektif dan untuk itu dibutuhkan pengetahuan tentang perilaku manusia dan kemampuan untuk mengelolanya. Oleh karena itu penyusunan strategi sumber daya manusia juga harus relevan dengan strategi bisnis, dan sangat membutuhkan komitmen serta keterlibatan yang lebih tinggi dari seluruh staf manajemen sumber daya manusia untuk memenangkan persaingan bisnis.

Salah satu sumber organisasi yang memiliki keunggulan kompetitif adalah produk yang dihasilkan bersifat unik, berbeda dengan produk yang dihasilkan organisasi lain. Persaingan konvensional yang menekankan pada kehandalan seperti efisiensi biaya, kemajuan teknologi, kecepatan distribusi, efisiensi produksi dan pengembangan karakteristik produk, akan lebih cepat dan mudah untuk ditiru. Andalan dalam globalisasi dan persaingan tinggi ini sebaiknya mengedepankan keunggulan kapabilitas baru organisasi seperti kecepatan, responsibilitas, fleksibiltas, kemampuan pembelajaran dan kompetensi terutama pada sumber 
daya manusianya. Seringkali dalam menghadapi persaingan yang kompetitif, dibarengi dengan kondisi yang penuh ketidakpastian. Hal ini memerlukan keahlian tersendiri dalam merumuskan strategi bisnis yang bisa meningkatkan keunggulan kompetitif dibanding pesaingnya untuk kelangsungan bisnis jangka panjang. Pimpinan organisasi harus mempelajari secara lebih mendalam bagaimana sumber daya manausia dapat diandalkan untuk memenangkan persaingan bisnis. Organisasi juga memerlukan sumber daya manusia yang mampu menempatkan organisasi lebih kompetitif dalam jangka yang lebih panjang, salah satunya dengan menciptakan diferensiasi terhadap organisasi lain, dimana manusiamanusia di dalamnya harus memiliki kemampuan menerapkan pengetahuan yang terbaik dan tepat dalam organisasinya. Manajer organisassi sepantasnya mengelola dengan baik sumber daya manusia yang ada, karena sumber daya manusia ini mempunyai peran kunci dalam memenangkan persaingan bisnis yang penuh ketidakpastian ini. Kekayaan intelektual dan pengetahuan yang dimiliki sumber daya manusia adalah aset berharga organisasi agar unggul dalam persaingan sehingga perlu pengelolaan yang baik. Sumber daya manusia menjadi aset strategis yang menentukan kesuksesan dan kelangsungan hidup organisasi dalam jangka panjang.

\section{KERANGKA PEMIKIRAN TEORITIS}

Fungsi sumber daya manusia harus menanggalkan peran administratif tradisionalnya dan mengadopsi peran bisnis baru yang terkait dengan pengembangan organisasi dan kapabilitas sumber daya manusia perusahaan, sebagaimana ditunjukan pada table 1 .

\section{Tabel 1}

\begin{tabular}{lll}
\hline \multicolumn{1}{c}{ Dari } & \multicolumn{1}{c}{ Menjadi } \\
\hline - Administrator & - Strategist \\
- Reaktif & - Proaktif \\
- Pengikut (follower) & - Pemimpin (leader) \\
- Employee advocate & - Employee champion \\
- Controller & - Partner bisnis \\
- Pelaksana pada pengendalian & - Fokus pada pengembangan kompetensi \\
\hline
\end{tabular}

\section{Sumber: Diolah dari Ulrich (1997)}

Pada gambar 1, disajikan empat peran sumber daya manusia yaitu manajemen sumber daya manusia yang strategis, manajemen infrastruktur perusahaan, manajemen kontribusi karyawan, dan manajemen transformasi dan perubahan. 


\section{Gambar 1}

Peran SDM Dalam Mengembangkan Organisasi Kompetitif

\section{Strategik}

\begin{tabular}{|c|c|c|}
\hline Proses & $\begin{array}{l}\text { Management of Strategic Human } \\
\text { Resources }\end{array}$ & $\begin{array}{r}\text { Management of } \\
\text { Transformation and Change }\end{array}$ \\
\hline & $\begin{array}{l}\text { Management of Firm } \\
\text { Infrastructure }\end{array}$ & $\begin{array}{r}\text { Management of Employee } \\
\text { Contribution }\end{array}$ \\
\hline
\end{tabular}

Sumber: Adaptasian dari Ulrich (1997)

Ulrich (1998) menunjukkan peran sumber daya manusia melalui peran menjadi partner para manager senior dan lini dalam melaksanakan strategi atau strategic partner, menjadi ahli administrasi, menjadiemployee champion dan agen perubahan. Gambar 2 menunjukkan model konseptual peran sumber daya manusia yang diusulkan Ulrich.

Gambar 2

Fungsi SDM Sebagai Partner Bisnis

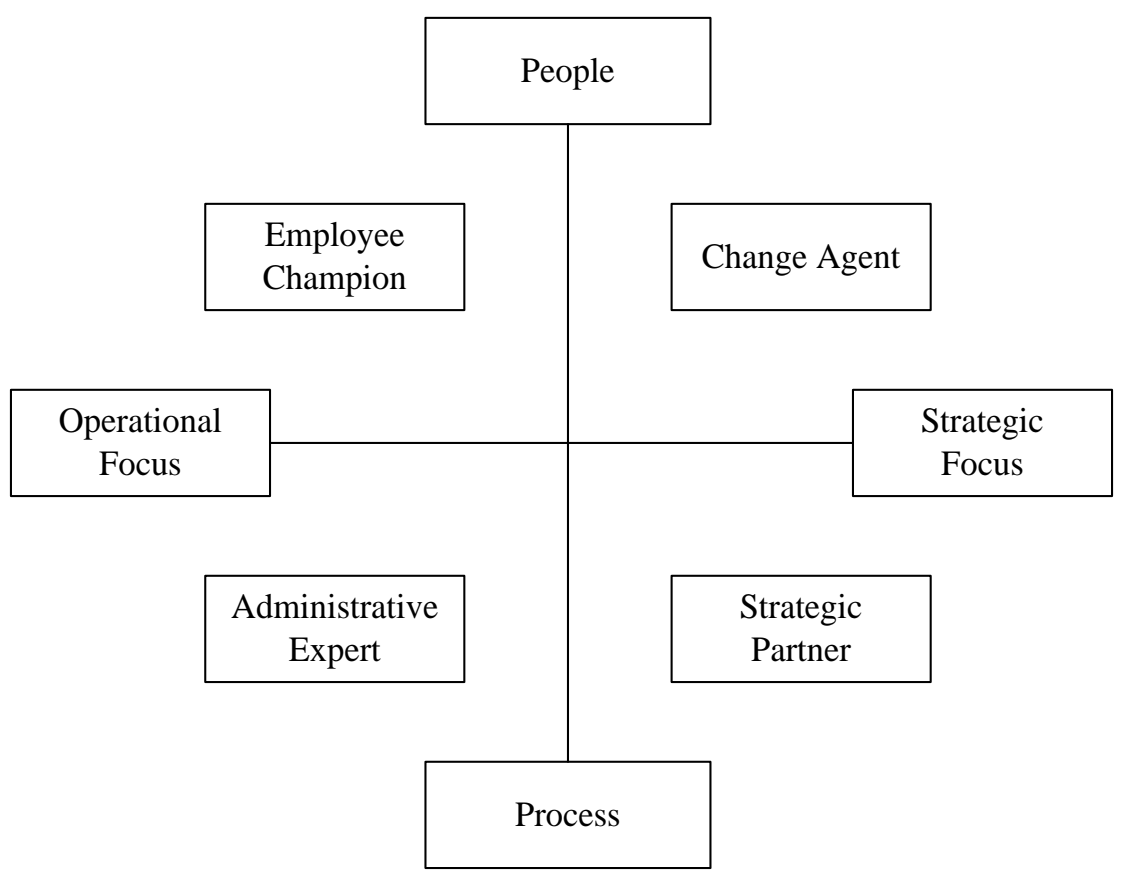

Sumber: Adaptasian dari Ulrich (1997) 
Ulrich (1997) lebih lanjut menguraikan pandangannya tentang empat peran baru sumberdaya manusiaut seperti disajikan pada table 2 berikut ini:

Tabel 2

\section{Reformulasi Peran dan Fungsi Partner Bisnis}

\begin{tabular}{|c|c|c|c|}
\hline Peran & Fungsi & Hasil & Kegiatan \\
\hline $\begin{array}{l}\text { Partner } \\
\text { Strategik }\end{array}$ & $\begin{array}{l}\text { Manajemen } \\
\text { SDM strategic }\end{array}$ & Eksekusi strategi & $\begin{array}{l}\text { Pengkaitan MSDM dengan } \\
\text { strategi bisnis: Diagnosis } \\
\text { organisasional }\end{array}$ \\
\hline $\begin{array}{l}\text { Ahli } \\
\text { administratif }\end{array}$ & $\begin{array}{l}\text { Manajemen } \\
\text { infrastruktur } \\
\text { organisasional }\end{array}$ & $\begin{array}{l}\text { Pengembangan } \\
\text { infrastruktur } \\
\text { organisasional yang } \\
\text { kondusif }\end{array}$ & $\begin{array}{l}\text { Reengineering proses } \\
\text { organisasional }\end{array}$ \\
\hline $\begin{array}{l}\text { Employee } \\
\text { Champion }\end{array}$ & $\begin{array}{l}\text { Manajemen } \\
\text { kontribusi } \\
\text { karyawan }\end{array}$ & $\begin{array}{l}\text { Peningkatan } \\
\text { komitmen dan } \\
\text { kapabilitas karyawan }\end{array}$ & $\begin{array}{l}\text { Pelibatan manajemen lini } \\
\text { dalam MSDM: Penyediaan } \\
\text { sumberdaya ke karyawan }\end{array}$ \\
\hline $\begin{array}{l}\text { Agen } \\
\text { Perubahan }\end{array}$ & $\begin{array}{l}\text { Manajemen } \\
\text { transformasi dan } \\
\text { perubahan }\end{array}$ & $\begin{array}{l}\text { Pengembangan } \\
\text { bentuk dan budaya } \\
\text { organisasi baru }\end{array}$ & $\begin{array}{l}\text { Pengelolaan transformasi } \\
\text { dan perubahan: } \\
\text { Pengembangan kapabilitas } \\
\text { untuk berubah }\end{array}$ \\
\hline
\end{tabular}

Sumber: Diolah dari Ulrich (1997)

\section{METODE}

Metode dan pendekatan yang digunakan dalam studi ini adalah studi kepustakaan. Stusi kepustakaan ini meliputi jurnal hasil penelitian dan berbagai buku manajemen sumber daya manusia.

\section{PEMBAHASAN}

\section{Mindsets Baru Tentang Manajemen Sumber Daya Manusia}

Realitas persaingan baru menuntut fungsi manajemen sumber daya manusia baru menjadi semakin profesional dan meninggalkan berbagai mitos dan cara tradisional. Pada mitos lama manajemen sumber daya manusia lebih memfokuskan pada biaya, yang mana biaya tersebut harus dikontrol. Hal ini berbeda dengan perkembangan saat ini bahwa berbagai praktek manajemen sumber daya manusia harus menciptakan nilai pelanggan melalui pengembangan kompetensi atau intellectual capital dalam organisasi. Jadi, fungsi manajemen sumber daya manusia harus menambah nilai, tidak sekedar mengurangi biaya. Pemahaman lama menyatakan bahwa setiap orang dapat melakukan manajemen sumber daya manusia. Sementara realitas baru 
sekarang ini bahwa berbagai kegiatan manajemen sumber daya manusia harus didasarkan pada konsep (teori) dan hasil penelitian, bukan sekedar "seni" dan common sense. Staf fungsi manajemen sumber daya manusia harus menguasai teori dan praktek secara profesional. Pada mitos lama, fungsi manajemen sumber daya manusia menangani berbagai masalah personalia. Sementara tuntutan realitas baru bahwa fungsi manajemen sumber daya manusia tidak dirancang untuk memberikan terapi atau sebagai lembaga sosial yang hanya menampung keluhan dan menyelesaikan berbagai masalah. Melainkan, fungsi manajemen sumber daya manusia harus mengembangkan berbagai praktek yang membuat para karyawan lebih kompeten dan lebih kompetitif.

Paradigma lama menekankan manajemen sumber daya manusia lebih pada kinerja operasional. Tetapi tuntutan sekarang ini bahwa dampak berbagai praktek manajemen sumber daya manusia pada kinerja strategik dan operasional dapat dan harus diukur. Fungsi manajemen sumber daya manusia harus dapat menerjemahkan berbagai kegiatannya ke dalam ukuran kerja strategik dan operasional. Pandangan terdahulu menganggap bahwa manajemen sumber daya manusia menjadi pekerjaan orang-orang personalia. Sementara sekarang ini menutnut para manajer lini mempunyai peran sangat penting dan harus terlibat secara aktif dalam kegiatan manajemen sumber daya manusia. Pengelolaan dan pengembangan sumber daya manusia terlalu penting jika hanya diserahkan kepada fungsi manajemen sumber daya manusia. Pemecahan berbagai isu sumber daya manusia mensyaratkan kerjasama antara fungsi manajemen sumber daya manusia dan manajemen lini. Manajemen sumber daya manusia sarat dengan fadsdanlip services. Berbagai praktek manajemen sumber daya manusia telah berkembang semakin profesional, tidak hanya dipenuhi dengan jargon yang mudah diucapkan, tetapi sulit dilaksanakan. Tuntutan persaingan mensyaratkan peran sentral fungsi manajemen sumber daya manusia dan perubahan kompetensi pada staf fungsi manajemen sumber daya manusia.

\section{Prinsip-Prinsip Pengembangan Fungsi Sumber Daya Manusia}

Strategi sumber daya manusia harus dikaitkan dengan dan didasarkan pada strategi bisnis. Manajemen sumber daya manusia juga bukan hanya sekedar tentang program, tetapi bagainaba sumber daya manusia tersebut dihubungankan dengan bisnis. Departemen sumber daya manusia harus dikenal sebagai organisasi yang mengantisipasi perubahan dan memahami apa kebutuhan untuk mengimplementasikannya. Fungsi sumber daya manusia juga harus menyeimbangkan kepentingan para karyawan dan kepentingan pengembangan bisnis perusahaan (person-job fit, dan person-business fit). Keefektifan sumber daya manusia tergantung pada strategi bisnis dan memfokuskan pada isu bisnis terkini. Eksekutif sumber daya manusia harus menerima bahwa pembelajaran dan peningkatan keahlian secara konstan adalah esensial untuk menjadi kontributor bagi bisnis perusahaan.

\section{Perubahan Peran Sumber Daya Manusia}

Dalam menghadapi berbagai tantangan bisnis perlu mengembangkan peran yang multi-fungsi manajemen sumber daya manusia sebagai suatu rencana bagi para profesional sumber daya manusiagunamelakukan kerjasama bisnis. Peran multi-fungsi ini akan menjadikan para profesional sumber daya manusiaterus melakukan pembelajaran bagaimana peran profesional dan amat strategis ini senantiasa terus meningkat dan membuahkan kinerja hasil yang baik dan memenuhi harapan dalam pelaksanaannya.

Peran sumber daya manusia sebagai pengembang organisasi kompetitif tersebut adalah; management of strategic human resoources (strategic partner), management of infrasructure (administrative expert), management of employee contribution (employee champion), management of transformation and change (change agent). Strategi sumber daya manusia dan strategi bisnis adalah peranan utama sumber daya manusia saat ini. Guna menciptakan dan meningkatkan nilai, peran baru sumber daya manusia ini telah ditentukan, 
karena adanya perubahan dalam masalah-masalah operasional hingga masalah-masalah strategis.

Oleh karena itu para profesional sumber daya manusia harus mampu memenuhi peran bukan sebatas pada isu pergeseran operasional maupun peran strategis, kualitatif maupun kuantitatif, jangka pendek maupun jangka panjang.

\section{Peran Partner Strategik}

Strategic Patner adalah mitra manajer senior dan manajer lini untuk melaksanakan strategi yang telah direncanakan, menterjemahkan strategi bisnis ke dalam implementasi melalui diagnosis. Sistem penilaian (assesment) serta penggabungan praktek organisasi dengan tujuan bisnis yang dapat dibangun di setiap tingkat organisasi. Penciptaan kondisi ini melibatkan sejumlah langkah seperti; menentukan atau mendefinisikan arsitektur organisasional, melaksanakan audit organisasional, mengidentifikasi metode untuk memperbarui bagian-bagian arsitektur organisasional yang membutuhkannya, mengadakan pemeriksaan tentang pekerjaannya sendiri dan menentukan prioritas.

Profesional sumberdaya manusia juga harus mampu mendorong terselenggaranya perbincangan tentang bagaimana organisasi mengeksekusi strateginya. Empat langkah yang dilakukan adalah: mendefinisikan arsitektur organisasional, malakukan audit organisasional, mengindentifikasi metode renovasi organisasional, dan mengambil inisiatif dan menyusun prioritas. Peran ini memfokuskan pada penggabungan strategi dan praktik-praktik sumberdaya manusia dengan strategi bisnis secara bersesuaian.

Para profesional sumberdaya manusia bekerja untuk menjadi mitra strategik, membantu memastikan kesuksesan strategi bisnis. Melalui pelaksanaan peran ini, para profesional sumbardaya manuisa meningkatkan kapasitas pelaksanaan strategi bisnis melalui partisipasi peran strategic. Eksekusi strategi bisnis yang diimplementasikan ke dalam praktik sumberdaya manusia akan meningkatkan kinerja bisnis melalui tiga cara yakni; memungkinkan bisnis mengadaptasi perubahan, dapat memenuhi permintaan pelanggan, danmencapai kinerja keuangan yang tinggi karena eksekusi strategi yang lebih efektif.

\section{Peran Ahli administratif}

Peran sebagai administrative expert, manajemen sumber daya manusia harus menjadi ahli dalam pelaksanaan pekerjaan dan efisiensi administrasi agar memperoleh hasil dengan biaya rendah dan berkualitas. Peran ini menfokuskan pada kemampuan manajemen sumber daya manusia dalam merekayasa ulang proses kerja menjadi lebih baik, mendefinisikan peran manajemen sumber daya manusia dalam menciptakan nilai organisasi, menciptakan mekanisme pendistribusian pelayanan manajemen sumber daya manusia, mengukur kinerja dari segi efisiensi sumber daya dan efektivitas dalam hal administrasi pengelolaannya.

Permasalahan yang semestinya dipertimbangkan dalam perannya sebagai administrative expert, yakni hasil utama efisiensi administrasi, mengoperasionalkan infrastruktur organisasi, dan menjadi pemimpin kegiatan yang diarahkan pada perekayaan ulang (reengineering) proses pekerjaan yang sedang ditangani. Berdasarkan pada hal tersebut, maka untuk meningkatkan peran administrative expert mensyaratkan persiapan yang berupa sistem, proses, dan praktik-praktik manajemen sumber daya manusia yang efektif dan efisien.

Peran ini dilakukan oleh manajer sumber daya manusia guna memperoleh metode yang efisien untuk menyelesaikan pekerjaan yang dinamakan proses perekayasaan ulang (reengineering). Reengineering dalam lingkungan sumber daya manusia dilakukan dengan cara menekankan layanan dengan menciptakan infrastruktur memadai untuk memperbaiki 
proses sumber daya manusia yang efisien pada proses maupun bisnis sumber daya manusia. Manajemen sumber daya manusia juga harus sedapat mungkin membantu organisasi dengan cara perekayasaan ulang proses bisnis.

Ketika organisasi mengidentifikasi dan memperbaiki proses utamanya, manajemen sumber daya manusia dapat membantu secara lebih aktif seperti pelayanan perbaikan kerja tim yang diarahkan kepada penyederhanaan, efisiensi, dan efektivitas. Disisi lain, manajemen sumber daya manusia juga harus menerapkan keahlian administratifnya dalam proses sumber daya manusia. Meskipun tidak diundang dalam proses penataan ulang organisasi, manajemen sumber daya manusia harus mendemonstrasikan kemampuannya untuk memberikan pelayanan sumber daya manusia secara efisien dengan menata ulang proses manajemen sumber daya manusia sendiri jika dibutuhkan.

Dengan menjalankan tugas ini, manajemen sumber daya manusia bukan saja memperbaiki infrastruktur organisasi melainkan pula memperoleh kredibilitas dalam partisipasi aktif untuk mengupayakan perubahan organisasi selanjutnya. Dalam rekayasa ulang (reengineering) bisnis maupun proses, manajemen sumber daya manusia pada akhirnya mampu memberi nilai pada dua fase yang berlaku pada upaya perekayasaan ulang (reengineering). Dua fase yang tersebut adalah improving process dan rethinking HR value creation.

Fase pertama, improving processes menerapkan prinsip perekayasaan ulang bisnis untuk memperbaiki proses sumber daya manusia. Dalam fase ini manajemen sumber daya manusia mengidentifikasi dan berusaha memahami proses yang kurang bermanfaat serta mencoba menemukan metode baru sebagai alternatif memberikan perbaikan pelayanan. Fase kedua, rethinking $H R$ value creation, merupakan proses berpikir ulang tentang bagaimana menciptakan nilai bagi sumber daya manusia. Penciptaan nilai ini akan berjalan di luar proses reengineering guna menatadan memikirkan kembali konsepi dan metode penyelesaian pekerjaan.

\section{Peran Pejuang (employee champion)}

Peran sebagai employee champion menjadikan manajemen sumber daya manusia pada gilirannya akan sebagai penengah antara karyawan dan manajemen agar kepentingan kedua belah pihak dapat dipenuhi. Sumberdaya manusia harus berbuat yang lebih banyak lagi secara terus menerus dan berkelanjutan agar komitmen dan kontribusi mereka meningkat. Organisasidengan modal intelektual yang dimiliki akan menjadi sumberdaya kritis dan bernilai bagi organisasi, dengan dengan demikian profesional sumberdaya manusia akan lebih mengarahkan perilakunya kepada sukses organisasi.

Profesional sumberdaya manusia sewajarnya memahami kebutuhan karyawan dan memastikan bahwa kebutuhan mereka telah terpenuhi. Dengan cara ini dapat dipastikan kontribusi karyawan meningkat bagi organisasi.Sumber daya manusia juga sewajarnya menjadi champion bagi karyawan yang diwakili ketika berhadapan dengan manajemen senior, sehingga meningkatkan kontribusi karyawan melalui komitmen dan kemampuannya terhadap organisasi.

Hal penting yang seharusnya dimiliki dalam peran baru ini adalah bahwa sumber daya manusia profesoinal memegang tanggung jawab guna memastikan para karyawan diikutsertakan dan memiliki komitmen serta memberi kontribusi maksimal bagi sukses organisasi. Sumber daya manusia sepantasnya mengambil peran dan tanggung jawab aktif guna memberikan orientasi dan pelatihan prefesional bagi manajemen lini dalam hal pentingnya moral karyawan yang tinggi serta bagaimana pencapaiannya. 
Fungsi sumber daya manusia memiliki peran kritis terutama ketika merekomendasikan cara-cara mengatasi masalah moral karyawan. Peran sumber daya manusia juga harus mewakili dan menjadi suara karyawan dalam forum-forum diskusi dengan pihak manajemen. Sumber daya manusia senantiasa menawarkan kesempatan untuk pertumbuhan profesional dan pribadi, sehingga memberi tempat yang layak guna membantu para karyawan melaksanakan kewajiban yang dipegang.

\section{Peran Agen perubahan}

Peran sumber daya manusia sebagai agen perubahan, memainkan proses dan budaya yang menaikkan kapasitas organisasi melalu perubahan. Peran sumber daya manusia harus secara maksimal menjadi agen transformasi yang membentuk proses dan budaya yang dapat meningkatkan kapabilitas organisasi terhadap perubahan. Sumberdaya manusia harus berperan membangun kapasitas organisasional guna mengkapitalisasi perubahan yang terjadi baik factor internal maupun eksternal sebagai pemicu perubahan tersebut.

Perubahan mengorientasikan pada penciptaan tim yang berkinerja tinggi dalam mengimplementasikan teknologi baru yang diadopsi untuk dikembangkan dan disampaikan melalui cara-cara tertentu dan pada waktu tertentu. Tantangan yang paling berat bagi organisasi adalah tantangan untuk merubah budaya organisasi. Untuk melahirkan budaya baru, sumberdaya manusia harus melakukan empat langkah, yakni: mendefinisikan dan menjelaskan konsep perubahan budaya, membuat pernyataan mengapa budaya menjadi pemicu keberhasilan bisnis, mendefinisikan proses pemahaman budaya yang sedang berjalan dan budaya baru yang hendak dibentuk, serta memastikan apakah masih terdapat kesenjangan diantara keduanya, dan mengidentifikasi pendekatan alternatif terhadap penciptaan budaya baru.

\section{Penciptaan Strategic Alignment}

Untuk menjadikan partner bisnis, harus terjalin kesesuaian yang kuat antara manajemen sumber daya manusia ditingkat implementasi dengan strategi bisnis atau korporat. Kesesuaian yang dimaksud dalam hal ini adalah bahwa program dan praktek sumber daya manusia mempunyai hubungan yang integrative dengan postur strategic (misi, visi, nilai, tujuan, dan strategi) dan berbagai perubahan yang terkait dengan bisnis dan lingkungan.

Selanjutnya di dalam praktek manajemen sumber daya manusia hendaknya implementasi itu berfokus dan diintegrasikan secara vertical dengan strategi bisnis, serta secara horizontal antara praktek manajemen sumber daya manusia tersebut terintegrasi dengan baik. Pengintegrasian tersebut mempunyai sasaran eksternal dan internal. Sasaran eksternal mengupayakan pencocokan dengan strategi bisnis, sedangkan pencocokan internal meng-konsistenkan dan mensinergikan antar praktek. Pengintegrasian ini menfokuskan pada penciptaan kompetensi serta system manajemen sumber daya manusia yang fleksibel. 


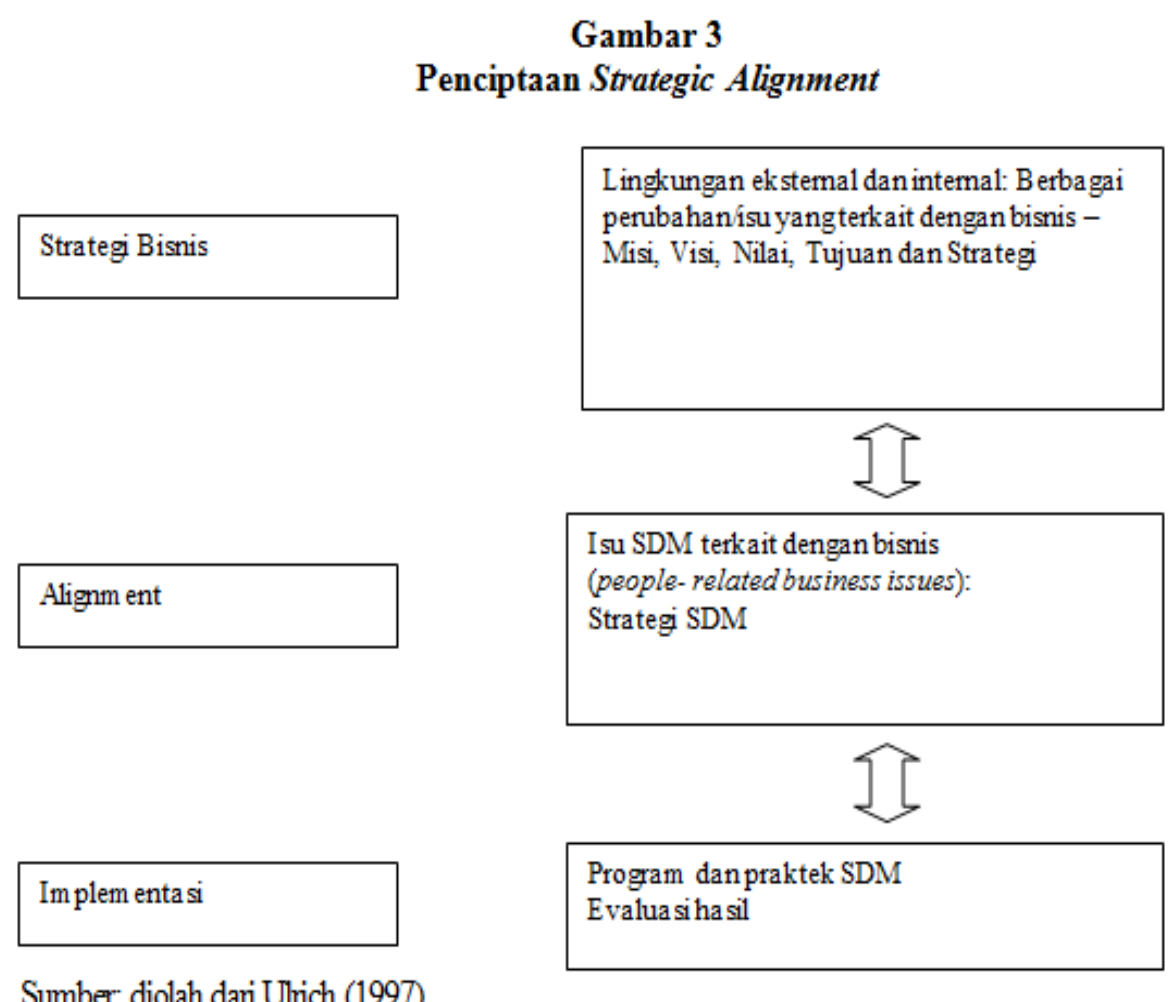

Dalam pengintegrasian strategi, system, dan praktek manajemen sumber daya manusia mempunyai potensi untuk mengembangkan keunggulan kompetitif berkelanjutan melalui pengembangan kompetensi yang firm specisic. Dengan kata lain, kompetensi sumber daya manusia yang dibangun erat kaitannya atau dipengaruhi oleh strategi bisnis, dan praktek manajemen sumber daya manusia, serta system manajemen sumber daya manusia dalam organisasi. Terakhir, Buller dalam kesempatan yang berbeda mengatakan bahwa ada empat tingkatan kesesuaian (alignment) antara fungsi sumber daya manusia dengan perencanaan strategic (bisnis). Keempat tingkatan alignment tersebut adalah; administrative linkage: fungsi sumber daya manusia memainkan peran personalia tradisional (tidak ada linkage dengan perencanaan strategik); one-way linkage: Fungsi sumber daya manusia dan perencanaan strategik (PS) mempunyai hubungan sekuensial, dengan aliran biasanya dari perencanaan strategik (PS) ke fungsi sumber daya manusia.; two-way linkage: Hubungan timbal balik dan saling ketergantungan antara perencanaan strategik (PS) dan fungsi sumber daya manusia; Integrative Linkage: Hubungan dinamik dan interaktif antara perencanaan strategik (PS) dan fungsi sumber daya manusia. Keempat peran baru yang dinyatakan oleh Ulrich (1997) itu akan berjalan dan mencapai hasil yang maksimal akan sangat tergantung pada tingkatan kesesuaian (alignment) antara fungsi sumber daya manusia dan perencanaan strategic (bisnis). Jika organisasi sudah berada pada tingkatan integrative linkage, maka keempat peran baru tersebut mencapai hasil yang paling maksimal.

\section{PENUTUP}

Peran baru sumber daya manusia bertanggung jawab dalam membangun kemampuan organisasi memanfaatkan peluang eksternal. Sumber daya manusia harus meyakinkan bahwa inisiatif perubahan yang memfokus pada kinerja teams, implementasi teknologi yang baru, dikembangkan dan disampaikan dengan cara yang tepat pada waktunya. 
Peran baru sumber daya manusia juga harus meyakinkan bahwa pernyataan visi yang secara ditransformasikan ke dalam perilaku organisasional, dengan membantu karyawan untuk memahami pekerjaan mana yang harus diselanjutkan dan mana yang segera dihentikan. Berkaitan dengan peran baru sumber daya manusia, bahwa untuk menjadi partner yang maksimal, sumber daya manusia harus menjadi ahli melalui kontribusi fungsinya. Dengan kata lain, sumber daya manusia harus menjadi agen perubahan yang mengawal penilaian ulang berbagai praktik manajemen yang tengah berjalan.

Tabel 3

Kritera Sukses Partner Bisnis

\begin{tabular}{|l|l|}
\hline \multicolumn{1}{|c|}{ Peran SDM } & \multicolumn{1}{c|}{ Kriteria Sukses } \\
\hline Partner Strategik & - Kepedulian pada bottom line \\
& - Memahami pasar dan bisnis \\
& - Menjamin sukses eksekusi strategi \\
& - Mempunyai visi jangka panjang orientasi dan arah bisnis \\
& - Menterjemahkan stratregi dalam kegiatan MSDM \\
& - Menentukan kekuatan\& kelemahan \\
\hline Ahli & - Mengembangkan proses MSDM yang efisien untukmendukung \\
Administratif & pencipataan "habitat" organisasi \\
& - Menciptakan infrastruktur organisasional melalui penilaian \\
& danperbaikan proses MSDM \\
& - Meengarah pada reengineering prosespekaerjaan secara kontinu \\
& - Menganalisis dan memberikan tanggapan \\
& terhadapkebutuhanorganisasioanl \\
\hline Pejuang & - Memahami berbagai SDM potensial dalam mengantisipasi \\
Karyawan & kebutuhan pengembangan mereka \\
& - Mengidentifikasi kompetensi yang dibutuhkan untuk \\
& mengeksekusi strategi sekarang dan mendatang \\
& - Mempunyai kapabilitas manajemen pendidikan dan pelatihan \\
& - Menganalisis cara penyediaan sumberdaya yang \\
& dibutuhkan karyawan dalam memenuhi tantangan baru \\
& - Mengembangkan komitmen terhadap tindakan \\
\hline Agen Perubahan & - Mengimplementasikan perubahan strategi \\
& - Mengembangkan pembelajaran organisasional dantim kerja serta \\
& membina hubungan \\
& - Menciptakan sense of urgency \\
& - Mampu berfikir konseptual dan mengartikulasi pemikiran \\
- Mempunyai sense of purpose malalui fokus dan sistem nilai
\end{tabular}

Sumber: Adaptasian dari Ulrich (1997).

Seluruh sumber daya manusia secara bersama-sama dengan manajemen lini harus sinergi dalam mengambil keputusan dan tindakan, bukan sekedar saran. Hal ini berarti bahwa sumber daya manusia harus memahami situasi masing-masing dan mendukung para manajer secara aktif untuk mencapai perubahan yang ingin dicapai. Peran baru sumberdaya manusia sebagai mitra strategik, ahli administratif, employee champion, dan agen perubahan dalam 
tiap organisasi berbeda-beda, termasuk heterogenitas atau homogenitas pelaksanaandan hubungan antar berbagai peran dimaksud.

Akhirnya, peran-peran tersebut mensyaratkan kemampuan dan keahlian baru agar menghasilkan kinerja yang diharapkan. Oleh karenanya, kemapuan dan keahlian sudah sewajarnya diimplementasikan secara berlebih berkelanjutanguna memperoleh keberhasilan organisasi. Untuk memastikan hal ini, perlu ada kriteria sukses dari setiap peran baru sumber daya manusia, seperti disajikan pada table 3 .

Profesionalsumber daya manusia, acapkali disebut sebagai mitra bisnis, yangsecara sempit diartikan sebagai profesional sumberdaya manusia yang bekerja dengan manajermanajer umum untuk mengimplementasikan strategi sebagai mitra strategik. Saat ini pengertian mitra bisnis telah banyak berubah, bukan saja sebagai mitra strategik, melainkan pula sebagai ahli administratif, employee champion dan agen perubahan.

\section{DAFTAR PUSTAKA}

Dave Ulrich, Justin Allen, B. Wayne, Jon Younger, and Mark Nyman. 2009. HR Transformation; Building Human Resources From The Outside In. New York. MacGraw-Hill.

Dave Ulrich. 1997. Human Resource Champion; The Next Agenda For Adding Value and Delivering Result. Boston. Havard Business School Press.

Jill Conner, Colgate-Palmolive, and Dave Ulrich. 1996. Human resources roles; creating value, not retoric. Human Resource Planning. Vol 19 (3). Pp. 38-49

Joan Lancourt and Charles Savage. 1995. Organizational transformation and the changing role of the human resource function. Compensatiom \& Benefits Management. Autum. Pp. $42-49$

Paul F. Buller....... Successful partnership; HR and strategic planning at eight top firm. Organizational Dynamics. Pp. 27-43 